\title{
5. Indigenous Cultural Heritage and Fair Trade: Voluntary Certification Standards in the Light of WIPO and WTO Law and Policy-making
}

\author{
Christoph B. Graber and Jessica C. Lai
}

\section{Introduction}

For a long time, the issue of trading indigenous cultural heritage $(\mathrm{ICH})^{1}$ was discussed with a defensive attitude. The question was generally how indigenous peoples could be protected against third parties misappropriating their knowledge assets in national or international trade. Academic writings adopting this approach seconded indigenous peoples fighting against old injustices stemming from unresolved problems of colonisation and a subjugation of their culture under Western law. Only very recently has a new wave of scholarship started to challenge this type of defensive thinking and tackle the issue of trading $\mathrm{ICH}$ from the development perspective. ${ }^{2}$ The question now is how trade in $\mathrm{ICH}$ can contribute to the economic and social development of indigenous peoples. The idea behind this approach is that an active participation in the trade of traditional cultural expressions (TCEs) and other traditional knowledge (TK) would offer indigenous peoples not only a source of income - allowing for a reduction of government aid dependency — but also a means for becoming architects of their proper future and, thus, increasing their sense of identity and dignity. Because ICH is a multidimensional asset, an important precondition for such indigenous empowerment would certainly be that the decision about which TCE can be traded and which TCE - because of its sacred or otherwise important meaning for a community - must not enter the market is a prerogative of the respective TCE- and TK-owning indigenous community.

\footnotetext{
1 Whereas indigenous cultural and intellectual property (ICIP) is a term also used to describe the subject matter, indigenous peoples often prefer to speak of indigenous cultural heritage (ICH). Accordingly, the latter term is used in this chapter.

2 An important step in this development was the launch of the Swiss National Science Foundation funded 'International Trade in Indigenous Cultural Heritage' research project in December 2009 at the University of Lucerne. This multi-year, international and trans-disciplinary project investigates how international law could be adjusted to allow indigenous peoples to actively participate in international trade with their cultural heritage without being constrained to renounce important traditional values. For more information see $<$ http://www.unilu.ch/deu/research_projects_135765.html>
} 
Recent developments at the level of international law and policy-making support efforts to view trade in $\mathrm{ICH}$ from a development perspective to some extent. The agenda of the World Trade Organization (WTO) Agreement on TradeRelated Aspects of Intellectual Property Rights (TRIPS Agreement) - as far as it deals with TK (including the relationship with the Convention on Biological Diversity (CBD)) - and the United Nations Educational, Scientific and Cultural Organization (UNESCO) are both sensitive to development considerations. ${ }^{3}$ Neither organisation, however, is much concerned with indigenous issues in particular. ${ }^{4}$ The World Intellectual Property Organization (WIPO) has recently included the development dimension into its agenda, and the documents produced by its Intergovernmental Committee on Intellectual Property and Genetic Resources, Traditional Knowledge and Folklore (IGC) since 2001 show that development is taken seriously. ${ }^{5}$ However, the IGC has been reluctant to clarify whether interests of indigenous peoples should be treated in a privileged manner.

An important shortcoming of all current initiatives at the international level is that they increase rather than reduce the existing fragmentation of the relevant law on ICH. There is also a risk that these top-down initiatives will be difficult to implement, since indigenous and non-indigenous stakeholders may have diverging views even on central matters of regulation. This chapter endeavours to take up an idea that has little been studied so far: that is, exploring the potential of bottom-up approaches, including private initiatives of voluntary certification standards, as alternatives to top-down approaches in the field of $\mathrm{ICH}$ and development. An interesting question to be addressed is whether the very successful Fairtrade labelling system could be extended to trade in ICH in a way likely to be accepted by indigenous peoples. A further question will be how such voluntary certification standards would relate to WIPO's draft provisions on TK/TCEs, and whether they would be in conformity with WTO/ TRIPS law and policy-making.

\footnotetext{
3 Strengthening the contribution of culture to sustainable development has been a goal of UNESCO policy-making since the launch of World Decade for Cultural Development (1988-1998). For most recent developments see below n 10 .

4 Although UNESCO stresses that its 'activities with indigenous peoples are framed by its missions to protect and promote cultural diversity, encourage intercultural dialogue and enhance linkages between culture and development', see <http://portal.unesco.org/culture/en/ev.php-URL_ID=35393\&URL_DO=DO_ TOPIC\&URL_SECTION $=201 . \mathrm{html}>$, its Convention on the Protection and Promotion of the Diversity of Cultural Expressions (CCD) (UNESCO, 2005), does not respond sufficiently to the interests of indigenous peoples. This is because the CCD was designed by its drafters to protect national entertainment industries rather than creative expressions of indigenous peoples. Indeed, a reference to TCE and indigenous peoples was introduced only at a late stage of the negotiations. Although the adopted text does mention TCE and indigenous peoples a few times, the relevant provisions do not address the rights of the indigenous peoples themselves, but those of the states whose territory is affected. See C B Graber, 'Institutionalization of Creativity in Traditional Societies and in International Trade Law' in S Ghosh and R P Malloy (eds), Creativity, Law and Entrepreneurship (Edward Elgar, 2011) 234, 247-248.

5 See below n 13.
} 


\section{ICH International Policy-making and the Problem of Top-down Approaches}

As most indigenous peoples appear in the lower end of socioeconomic statistics, the potential to generate an income from the trade of their cultural heritage - such as their designs, dances, songs, stories and sacred artwork - is not insignificant to their wellbeing. As recent research (including the Harvard Project on American Indian Economic Development) ${ }^{6}$ shows, there is evidence that economic development in Indian Country has finally gained traction across many reservations only after policies of self-determination took effect ${ }^{\prime} .{ }^{7}$ Similarly, we take the view that trade in indigenous knowledge assets may promote social and economic development of indigenous communities, ${ }^{8}$ provided that such trade is controlled by them. ${ }^{9}$ The requirement that indigenous communities decide beforehand whether a certain part of their cultural heritage may be traded must be a conditio sine qua non. The new scholarly approach to look at trade in $\mathrm{ICH}$ from a development perspective fits well with the growing international awareness of policy-makers that intellectual property (IP) and cultural expressions may be an important driver of social and economic development, including for indigenous peoples. As a follow-up to the 2010 UN Millennium Summit, the United Nations General Assembly adopted a resolution on culture and development on 20 December $2010 .{ }^{10}$ The resolution emphasises the important contribution of culture for sustainable development, and for the achievement of national and international development objectives, including the Millennium Development Goals. ${ }^{11}$ The 2008 UN Creative Economy Report

6 The Harvard Project on American Indian Economic Development has undertaken a comprehensive, systematic and comparative study of social, economic and political conditions of American Indian reservations over the last 20 years. See E C Henson et al (eds), The State of the Native Nations: Conditions under U.S. Policies of Self-determination (Oxford University Press, 2008).

7 Ibid 9.

8 For a more sceptical view on the question whether such commercialisation would be desirable as a consequence for indigenous peoples, see R K Paterson and D S Karjala, 'Looking Beyond Intellectual Property in Resolving Protection of the Intangible Cultural Heritage of Indigenous Peoples' (2003) 11 Cardozo Journal of International and Comparative Law 633, 634.

9 The requirement that trade in ICH must be controlled by indigenous communities is reflected at the level of international law by the United Nations Declaration on the Rights of Indigenous Peoples (UNDRIP). The UNDRIP emphasises collective rights of indigenous self-determination and self-government, including in cultural matters. Although the UNDRIP is not a binding instrument of international law and does not create new rights, it provides for a detailing and interpretation of the human rights enshrined in other international human rights instruments with universal resonance. See C B Graber, 'Aboriginal Self-Determination vs. the Propertisation of Traditional Culture: The Case of Sacred Wanjina Sites' (2009) 13(2) Australian Indigenous Law Review 18, 27.

10 See UNESCO Executive Office Sector for Culture, The United Nations Recognizes the Role of Culture for Development (2010) <http://portal.unesco.org/culture/en/ev.php-URL_ID=41466\&URL_DO=DO_ TOPIC\&URL_SECTION $=201 . \mathrm{html}>$

11 This resolution is noteworthy insofar as the eight Millennium Development Goals do not mention culture explicitly. See UN, Development Programme - What are the Millenium Development Goals? (2011) <http:// www.undp.org/mdg/basics.shtml> 
emphasised the link between the economy and culture as a 'new development paradigm', ${ }^{12}$ and WIPO started to look at IP from a development perspective in the framework of the WIPO Development Agenda. ${ }^{13}$ The scope of the latter includes knowledge assets of indigenous peoples in developing and developed countries. Development is also an issue in ongoing WIPO negotiations within the IGC, eventually leading to binding or non-binding international instruments on TK, genetic resources and TCEs. ${ }^{14}$

Although the discussions in the WIPO IGC on TCEs and TK have been ongoing for over ten years, little progress has been made. After twenty sessions of the IGC,15 no agreement is in view even with regard to the key objectives and principles of the new TCE (and TK) instrument, and views diverge between indigenous and non-indigenous stakeholders and often even between indigenous communities. For indigenous peoples, one central question is whether the new instruments should also extend to TCEs and TK of a non-indigenous origin. A further issue is that creating new WIPO instruments on TCEs and TK risks increasing rather than reducing the existing fragmentation of the relevant law on ICH. These difficulties have provoked critical comments questioning the feasibility of any top-down solution to the problem. ${ }^{16}$ Taking such criticism seriously, in this

12 According to the UN Creative Economy Report, The Challenge of Assessing the Creative Economy: Towards Informed Policy-making, UN Doc UNCTAD/DITC/2008/2 (2008), 3 'a new development paradigm is emerging that links the economy and culture, embracing economic, cultural, technological and social aspects of development at both the macro and micro levels. Central to the new paradigm is the fact that creativity, knowledge and access to information are increasingly recognized as powerful engines driving economic growth and promoting development in a globalizing world.' Chapter 6.4 of the report explicitly deals with TCEs. The report was drafted jointly by United Nations Conference on Trade and Development (UNCTAD) and United Nations Development Programme (UNDP) in cooperation with UNESCO, WIPO and International Trade Centre (ITC).

13 The WIPO Development Agenda was established by the WIPO General Assembly in October 2007. It includes a set of 45 recommendations designed to enhance the development dimension of the organisation's activities. Recommendation 18 (related to norm-setting, flexibilities, public policy and public domain) urges the IGC 'to accelerate the process on the protection of genetic resources, traditional knowledge and folklore, without prejudice to any outcome, including the possible development of an international instrument or instruments'. In addition to the adoption of the Development Agenda, WIPO member states also approved a recommendation to establish a Committee on Development and Intellectual Property. See generally the chapters in N W Netanel (ed), The Development Agenda: Global Intellectual Property and Developing Countries (Oxford University Press, 2009).

14 The idea of 'development' underlies the whole WIPO Draft on the protection of TCE. To this end, two objectives of the draft are relevant: objective (iii), which aims to 'contribute to the welfare and sustainable economic, cultural, environmental and social development of such peoples and communities'; and objective (xi), which aims to promote the development of indigenous peoples and communities and 'legitimate trading activities'. Objective (xi) promotes the use of TCE for the development of indigenous peoples and communities, where desired by them. Moreover, the objective recognises the TCE as 'an asset of the communities that identify with them, such as through the development and expansion of marketing opportunities for traditionbased creations and innovations'. See WIPO IGC Secretariat, The Protection of Traditional Cultural Expression/ Expression of Folklore: Revised Objectives and Principles, WIPO Doc WIPO/GRTKF/IC/17/4 (2010).

15 The 20th session of the IGC took place on 14-22 February 2012.

16 See P Drahos, 'A Networked Responsive Regulatory Approach to Protecting Traditional Knowledge' in D J Gervais (ed), Intellectual Property, Trade and Development: Strategies to Optimize Economic Development in a TRIPS-plus Era (Oxford University Press, 2007) 385. 
chapter we take up Peter Drahos's suggestion to think also about alternative bottom-up approaches to commercialising ICH. ${ }^{17}$ Since the prevention of fakes and reducing the market share of imitations would be crucial to enhance trade in $\mathrm{ICH}$, international law could assist indigenous peoples through the establishment of a system of origin certification that would work at the international level.

Such a strategy may also find support from indigenous brokers, since the United Nations Permanent Forum on Indigenous Issues recommended, in a 2003 report, that states should promote 'the knowledge, application and dissemination of appropriate technologies and indigenous peoples' local products with certificates of origin to activate product activities, as well as the use, management and conservation of natural resources' ${ }^{18}$ A prominent forum for discussing issues of origin of traditional knowledge assets is the CBD. Although the CBD focuses on TK that is associated with genetic resources, discussions on disclosure or certification of origin held therein may be relevant also for other forms of TK relating to the subject matter of IP applications. A report delivered by the United Nations Conference on Trade and Development (UNCTAD) on the invitation of the Seventh Conference of the Parties of the $\mathrm{CBD}^{19}$ shows that certificates of origin are important in the realm of the CBD 'to certify that the source of genetic resources and associated traditional knowledge has the authority to provide access on specified conditions, and also to certify the existence of ex ante benefit-sharing requirements that are compliant with the CBD and with relevant laws and equitable principles of the country providing such resources or knowledge' ${ }^{20}$ Beyond enabling access to TK associated with genetic resources and demonstrating prior informed consent and equitable benefit sharing (as a precondition for obtaining IP rights); ${ }^{21}$ certificates of origin may facilitate further commercial uses. If certificates of origin are linked with labelling systems or origin marks, they may be useful 'in promoting commercial recognition of the subject matter of intellectual property and in obtaining benefits for countries

\footnotetext{
17 Ibid.

18 UN Permanent Forum on Indigenous Issues, Recommendations Specifically Pertaining to Indigenous Women and the Girl Child, adopted by the Permanent Forum on Indigenous Issues, Report of the Second Session, UN Doc E/C.19/2003/22 (2003), 9; Drahos, above n 16, 402.

19 See UNCTAD, Analysis of Options for Implementing Disclosure of Origin Requirements in Intellectual Property Applications. A contribution to UNCTAD's response to the invitation of the Seventh Conference of the Parties of the Convention on Biological Diversity, UNCTAD Doc UNCTAD/DITC/TED/2004/14 (2006). In 2004, at its Seventh Meeting, the CBD Conference of Parties, in Decision VII/19, invited WIPO and UNCTAD to analyse issues relating to implementation of disclosure of origin requirements in the IP law system. Part VI of the report delivered by UNCTAD provides for an analysis of IP issues raised by international certificates of origin.

20 Ibid 69.

21 Prior informed consent and equitable benefit sharing are required under the Nagoya Protocol on Access to Genetic Resources and the Fair and Equitable Sharing of Benefits Arising from their Utilization to the Convention on Biological Diversity (2010), arts 4.1bis, 5.1bis, 5 bis, 9.
} 
and indigenous or local communities that exercise rights over genetic resources and associated traditional knowledge' ${ }^{22}$ The report cautions, however, that this may raise difficult questions regarding the 'authenticity' standard to be applied.

In fact, experiences with the Australian Authenticity Labels, certifying as 'authentic' goods and services deriving from a work of art created by an indigenous person or people, were negative. What were the reasons for this failure? Fairtrade, another example of voluntary certification standards, is by contrast a big success. Why is this? Fairtrade certification and its system of minimum pricing were designed for commodity products. Could one nonetheless learn from this model to avoid flaws, such as those identified in the Australian Authenticity scheme, and develop a model that would meet the interests of both indigenous peoples and consumers in a global market? These questions will be addressed in the next section.

\section{Voluntary Certification Standards and ICH}

\section{(a) Typical Features of a Voluntary Certification Standard}

In its most general description, a voluntary certification standard consists of three key elements, including: (1) voluntary standard-setting; (2) certification; and (3) labelling and marketing. ${ }^{23}$ When applied to $\mathrm{ICH}$, an essential requirement would be that all three elements are controlled by indigenous communities. Accordingly, voluntary standard-setting would typically consist of a process whereby indigenous peoples agree on minimal requirements that select cultural goods or services should meet. These standard requirements could relate to the origin of a good or service, its physical properties, or the process through which it is produced or commercialised. Certification then would involve an independent body examining whether the good or service at issue would actually conform to the set standard. Finally, labelling would make the conformity of a good or service with the standard visible to suppliers, intermediate buyers or end consumers and would, thus, allow for a specifically designed marketing campaign. To protect the label against misuse, it could be registered as a regular trade mark or certification mark according to the national law that is applicable.

22 UNCTAD, above n 19, 73.

23 M Chon, 'Marks of Rectitude' (2009) 77 Fordham Law Review 101, 105. 


\section{(b) Why Did the Australian Authenticity Label Fail?}

Voluntary certification standards have been used in several countries as a means to promote trade in $\mathrm{ICH} .{ }^{24}$ These had had varying success. For example, whereas the Alaskan 'Silver Hand' certification mark has been around since 1961, ${ }^{25}$ the New Zealand 'Māori Made' Toi Iho certification mark system was disinvested by the Government in 2009, as it had not achieved increased sales of Māori art by licensed artists or retailers. ${ }^{26}$ Since the Australian Authenticity Label has been widely commented upon, we will have a closer look at this scheme and ask why it failed only two years after its introduction.

The Australian Authenticity Label was launched in 1999 along with a 'Label of Collaboration' ${ }^{27}$ The Label of Authenticity was for 'authentic' goods or services which were 'derived from a work of art created by an Aboriginal or Torres Strait Islander person or people, [and] reproduced or produced and manufactured by Aboriginal or Torres Strait Islander people'. ${ }^{28}$ The Label of Collaboration was for works that were a result of collaboration involving 'authentic' creation by an Aboriginal or Torres Strait Islander, and reproduction or production and manufacture by non-indigenous persons, under a licence (for the copyright of the work) from a fair and legitimate agreement. ${ }^{29}$ The purpose of the Australian Authenticity Labels was to maximise consumers' certainty 'that they were getting the genuine product', ${ }^{30}$ to promote Aboriginal and Torres Strait Islander authorship, ${ }^{31}$ and to help ensure a fair, equitable and improved return to indigenous authors. ${ }^{32}$

\footnotetext{
24 Australia, Canada, New Zealand and Portugal are examples of countries where certification marks have been used to ensure the authenticity and quality of indigenous artefacts, see WIPO, Intellectual Property Handbook: Policy, Law and Use (WIPO Publication 489, 2004) <http://www.wipo.int/about-ip/en/iprm/> para 2.306; D Zografos, Intellectual Property and Traditional Cultural Expressions (Edward Elgar, 2010) 103-42. 25 Zografos, above n 24, 114-119.

26 Creative New Zealand, 'Statement on toi iho ${ }^{\text {TM' }}$ (21 October 2001) <http://www.creativenz.govt.nz/ en/news/creative-new-zealand-statement-on-toi-iho $>$ The toi iho trade marks have been transferred to the Transition Toi Iho Foundation (made up of Māori) to continue the system.

27 M Rimmer, 'Australian Icons: Authenticity and Identity Politics' (2004) 3 Indigenous Law Journal 139, 141. The authenticity mark was officially registered in March 2000. Interestingly, the collaboration mark was not approved until August 2003, well after the marks had become defunct. See T Janke, Minding Culture: Case Studies on Intellectual Property and Traditional Cultural Expressions (WIPO, 2003) 140.

28 Board of Studies NSW, Protecting Aboriginal Indigenous Art: Ownership, Copyright and Marketing Issues for NSW Schools (Board of Studies NSW, 2006) 16.

29 Ibid 16; Janke, above n 27, 143.

30 See Drahos, above n 16, 402; see also Arts Law Centre of Australia, Certificates of Authenticity (2004) <http://www.artslaw.com.au/images/uploads/AITB_CertificatesOfAuthenticity.pdf>

31 J Anderson, 'The Politics of Indigenous Knowledge: Australia's Proposed Communal Moral Rights Bill' (2004) 27(3) University of New South Wales Law Journal 585, fn 76; see also M Annas, 'The Label of Authenticity: A Certification Trade Mark for Goods and Services of Indigenous Origin' (1997) 3(90) Aboriginal Law Bulletin 4.

32 Drahos, above n 16, 402; see also Annas, above n 31; Janke, above n 27, 145.
} 
Both labels were registered as 'certification marks' under the Australian Trade Marks Act. ${ }^{33}$ Whereas normal trade marks distinguish certain goods or services as those produced by a specific (natural or legal) person, certification marks indicate that the certified goods or services comply with a set of standards and have been certified by a certification authority. ${ }^{34}$ The marks were owned by the National Indigenous Arts Advocacy Association (NIAAA). ${ }^{35}$ The NIAAA was also the certification authority. In this function, the NIAAA certified that the protected goods or services complied with the required standard: that is, that they were or involved an 'authentic' creation by an Australian indigenous person. ${ }^{36}$

The first step required for use of the marks was registration to the NIAAA. To register an artwork or similar product, an artist had to show that he or she identified as Aboriginal or Torres Strait Islander. Artists also had to show that they indeed were indigenous by descent through providing two signed forms certified by an Aboriginal corporation and passed at a meeting. ${ }^{37}$ They also had to show that they were accepted as indigenous by a community, and had permission from the relevant community to make the artwork or product. ${ }^{38}$ For the Collaboration Label, the indigenous artist and the producer or manufacturer had to apply jointly. ${ }^{39}$ Once registered, the artist had permission to use the label on his or her artwork or product. ${ }^{40}$ Use had to comply with a set of rules, including that the works were created within indigenous customary law. ${ }^{41}$

33 See Trade Marks Act 1995 s 169 (Cth) stating that:

A certification trade mark is a sign used, or intended to be used, to distinguish goods or services:

(a) dealt with or provided in the course of trade; and

(b) certified by a person (owner of the certification trade mark), or by another person approved by that person, in relation to quality, accuracy or some other characteristic, including (in the case of goods) origin, material or mode of manufacture; from other goods or services dealt with or provided in the course of trade but not so certified.

34 A Taubman and M Leistner, 'Analysis of Different Areas of Indigenous Resources, Traditional Knowledge' in S von Lewinski (ed), Indigenous Heritage and Intellectual Property: Genetic Resources, Traditional Knowledge and Folklore (2nd ed, Kluwer Law International, 2008) 59, 127-129; WIPO, above n 24, paras 2.330-2.332.

35 NIAAA, Policy and Objectives (2011) < http://www.culture.com.au/exhibition/niaaa/about.htm> The NIAAA had indigenous leadership. However, this leadership was unstable and fluctuated constantly. Moreover, there was much debate as to whether the organisation was representative of all Aborigines, as it was perceived as a Sydney-based entity, rather than an association enjoying wider support. Email from Matthew Rimmer, 25 February 2011 [on file with the authors].

36 L Wiseman, 'Regulating Authenticity' (2000) 9(2) Griffith Law Review 248, 252.

37 Janke, above n 27, 142.

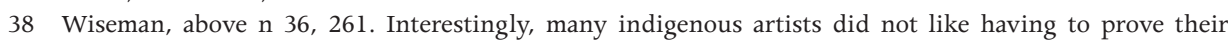
indigeneity and called it another 'Dog Tag' system.

39 Janke, above n 27, 143. Determining whether the contract between the indigenous artist and producer or manufacturer had 'fair trading terms' included assessing: (1) 'whether the Indigenous person who contributed to the work had the opportunity to obtain independent advice from NIAAA, an Arts Law Center or a legal adviser before signing the agreement'; and (2) 'whether the Indigenous person is required to assign their intellectual property rights in the work without additional payment of consideration'.

40 Arts Law Centre of Australia, above n 30, 1.

41 Janke, above n 27, 142. 
On the retail level, the two marks allowed an indigenous arts and crafts retailer to inform customers that he or she supported the Authenticity Labels and that his or her business operated under a NIAAA licence. Practically, this licensing arrangement was exhibited by a sticker to be affixed on shop windows or doors. ${ }^{42}$

The two Authenticity Labels existed only for two years. According to commentators, there were a number of reasons for this failure, including difficulties in defining 'authenticity' and insufficient funding of the system's administration. ${ }^{43}$ Difficulties in defining and monitoring what fell into the term 'authentic' were certainly the main factors in the system's failure. ${ }^{44}$ Definition involved value judgements about Aboriginal art and - as had been feared by members of the indigenous arts and crafts community - the distinction of two categories of authentic and non-authentic indigenous art. ${ }^{45}$ The NIAAA was criticised for introducing an 'authenticity' standard in a top-down way, without sufficient involvement of indigenous stakeholders. ${ }^{46}$ As a matter of fact, the NIAAA did not reflect that certain indigenous communities already had their own identification marks prior to the inception of the NIAAA marks. ${ }^{47}$ Moreover, artists who were part of local or regional art centres or organisations did not feel that they needed the NIAAA labels to denote the 'authenticity' of their products. ${ }^{48}$ Thus, the labelling system was never widely accepted or used by the indigenous peoples of Australia.

Commentators emphasised the impossibility of developing a common authenticity standard in an environment where there is little agreement among various indigenous groups regarding the concept of Aboriginal identity. In particular, rural and peripheral indigenous communities did not like the idea of a 'homogenising' national labelling system. ${ }^{49}$ And many urban indigenous artists were concerned that 'authentic' would denote indigenous art 'that employs traditional techniques, materials and imagery' ${ }^{50}$

There were flaws not only in the definition of 'authenticity' but also in the implementation of the standard. According to commentators, the NIAAA's lack

\footnotetext{
42 Ibid 144.

43 L Wiseman, 'The Protection of Indigenous Art and Culture in Australia: The Labels of Authenticity' (2001) 23(1) European Intellectual Property Review 14; Rimmer, above n 27; Drahos, above n 16, 402; Janke, above $\mathrm{n} 27,145$.

44 Rimmer, above n 27, 157.

45 Wiseman, above n 43, 14. According to Matthew Rimmer, the labels served to 'typecast Indigenous artists in a narrow and rigid fashion'; Rimmer, above n 27, 158.

$46 \mathrm{~J}$ Anderson, The Production of Indigenous Knowledge in Intellectual Property (PhD Thesis, University of New South Wales, 2003) 240; Rimmer, above n 27, 158-159.

47 Anderson, above n 46, 240-241; Wiseman, above n 36, 266-267.

48 Janke, above n 27, 147.

49 Rimmer, above n 27, 160.

50 Anderson, above $\mathrm{n} 46,240$. Wiseman noted that "[f]or urban and non-traditional artists, the way authenticity is defined raises the problem that they may be stigmatized for not being "real" or "authentic" Aboriginal artists' Wiseman, above n 43, 20. See also Wiseman, above n 36, 262.
} 
of independence made it too easy to show indigeneity and to get the marks. ${ }^{51}$ It seems obvious that independence cannot be assured in an organisational structure where - as in the case of the NIAAA - the owner of the mark also sets the standards and acts as the certification body.

Poor funding was considered to be a second main structural shortcoming of the Australian Authenticity scheme. Although the NIAAA received some funding from the Australia Council and the Aboriginal and Torres Strait Islander Commission, these funds were not sufficient to establish the scheme at a national and international level..$^{52}$ To make the labels work effectively, the NIAAA would have required more money for marketing campaigns to raise awareness of the labels among consumers and tourists. ${ }^{53}$ Commentators reckon that the lack of funding was also the reason all the responsibilities were given to the NIAAA rather than to a separate body established to undertake the certification role, as was recommended by Terri Janke prior to the launch of the labelling system. ${ }^{54}$

Besides these structural flaws, there were also shortcomings in the implementation and administration of the Australian scheme through the NIAAA. As a result of allegations of misappropriated funds and failures of accountability, the federal government's funding to the NIAAA was discontinued. ${ }^{55}$ The Aboriginal and Torres Strait Islander Arts Board of the Australia Council commissioned a review of the NIAAA in 2002. ${ }^{56}$ The review concluded that the NIAAA had poor governance and management, tended to focus on Sydney ${ }^{57}$ and under-represented other indigenous communities, set a problematic definition of 'authenticity', had problems implementing the system and failed to be financially accountable. The review also placed some blame on the funding agencies for not supervising the NIAAA and for creating a culture of non-accountability. ${ }^{58}$

\footnotetext{
51 D Jopson, 'Aboriginal Seal of Approval Loses its Seal of Approval' Sydney Morning Herald (online), 14 December 2002, <http://www.smh.com.au/articles/2002/12/13/1039656221205.html> Rimmer, above n 27, 159.

52 Drahos, above n 16, 403. The scheme was meant to be additionally financed through charging fees for applications and labels. However, the A $\$ 30$ registration for the Label of Authenticity and A $\$ 50$ for the Collaboration Label were considered to be prohibitive by many Aboriginal artists. This was because much of the artist community was made up of hobby artists whose income was insufficient to warrant the registration fee. See Wiseman, above n 36, 265; Janke, above n 27, 145.

53 Janke, above n 27, 146.

54 T Janke, Our Culture: Our Future: Report on Australian Indigenous Cultural and Intellectual Property Rights (Michael Frankel and Company Solicitors, 1998) 204, 207; Rimmer, above n 27, 164.

55 Anderson, above $\mathrm{n} 31$.

56 This report was not made public, but is discussed by Rimmer, above n 27, 161-164.

57 Where the NIAAA was based.

58 Rimmer, above n 27, 164.
} 


\section{(c) Could One Learn from the Fairtrade Label?}

In comparison with the failure of the Australian Authenticity mark, the success of the Fairtrade label is striking. The history of the Fairtrade system goes back to 1988, when Max Havelaar was founded as the first Fairtrade label under the initiative of the Dutch development agency Solidaridad. ${ }^{59}$ In the late 1980s to early 1990s, this initiative was replicated in several other markets in Europe and North America, each with its own mark. ${ }^{60}$ To unite all the existing labelling initiatives under one umbrella, and harmonise standards and certification worldwide, in 1997 the Fairtrade Labelling Organization International (FLO) was established in Bonn, Germany. ${ }^{61}$ The different labels remained until 2002, when the FLO launched the international FAIRTRADE Certification Mark and the former labels were gradually replaced..$^{62}$ Canada and the US still use their own labels. ${ }^{63}$

An overall concern of the fair trade movement is to fight for global justice and to equalise the north-south divide of producers in the world market for commodity products. ${ }^{64}$ Accordingly, the purpose of the Fairtrade labelling system is to help small-scale farmers and workers in developing countries. ${ }^{65}$ In addition to ensuring that suppliers are not unfairly exploited by the mechanisms of the global market, the Fairtrade system aims at contributing to social and environmental development in marginalised regions of the world. ${ }^{66}$ From its beginning, a characteristic of the Fairtrade scheme was its grassroots collaborative approach. ${ }^{67}$ Producers jointly own and manage the FLO, and producers are members on the Board of Directors. ${ }^{68}$ Accordingly, producers determine the direction that Fairtrade will head towards, and decisions are taken

59 The history of Fairtrade is outlined by the FLO, History of Fairtrade (2011) < http://www.fairtrade.net> and A Hutchens, Changing Big Business: The Globalisation of the Fair Trade Movement (Edward Elgar, 2009) 55-77.

60 Max Havelaar (in Belgium, Switzerland, Denmark, Norway and France), Transfair (in Germany, Austria, Luxemburg, Italy, the US, Canada and Japan), Fairtrade Mark in the UK and Ireland, Rättvisemärkt in Sweden, and Reilu Kauppa in Finland.

61 FLO, above $\mathrm{n}$ 59. On the crucial role of FLO International, see Chon, above n 23, 134-135.

62 FLO, About the Mark (2011) < http://www.fairtrade.net>

63 Ibid, the 'Fair Trade Certified' label.

64 For a history of the fair trade movement, see Zografos, above n 24, 143-149.

65 Producers must come from countries with low to medium development status in Africa, Asia, Oceania, Latin America and the Caribbean. The products must come from small farmer organisations (small producers, small-scale farmers) who do not depend on hired workers all the time, but run their farm mainly by using their own and their family's labour. Companies with hired labour may apply for certain products. See FLO, Geographical Scope of Producer Certification for Fairtrade Labelling (2009) < http://www.fairtrade.net/uploads/ media/Aug09_Geographical_scope.pdf>

66 FLO, Aims of Fairtrade Standards (2011) <http://www.fairtrade.net>

67 Chon, above $\mathrm{n} 23,115$.

68 FLO, Fairtrade is Unique (2009) <http://www.fairtrade.net/fileadmin/user_upload/content/2009/ resources/Fairtrade_is_Unique.pdf $>2$. 
in an open and inclusive fashion. ${ }^{69}$ In our view, the bottom-up, collaborative and open approach of the Fairtrade system makes an important contrast to the NIAAA and the Australian Authenticity Labels. As we have highlighted above, the NIAAA operated in a top-down manner, many indigenous communities were never consulted about the development of the marks, and most artists never felt that the mark was theirs.

Stakeholder involvement is an important element of Fairtrade standards. Whereas the Australian scheme was based on a NIAAA-imposed standard of 'authenticity', Fairtrade standards are set in accordance with the ISEAL Code of Good Practice for Setting Social and Environmental Standards. ${ }^{70}$ According to ISEAL requirements, Fairtrade standard-setting processes are open, and involve the major stakeholders in the system, including producers and the FLO. ${ }^{71}$ There are two sets of Fairtrade standards, for two different types of disadvantaged producers. ${ }^{72}$ One applies to smallholders who are working together in cooperatives or other organisations with a democratic and participative structure. For these, a generic producer standard is that profits should be equally distributed among the producers. Furthermore, all members need to have a voice and vote in the organisation's decision-making process. ${ }^{73}$ The other set of standards applies to workers, whose employers pay decent wages, guarantee the right to join trade unions (freedom of association), ensure health and safety standards, and provide adequate housing where relevant. Fairtrade standards also cover terms of trade. ${ }^{74}$ Most products have a Fairtrade price, meaning that companies trading Fairtrade products must pay a minimum amount to the producers (to cover the costs of sustainable production).${ }^{75}$ This price is periodically reviewed by the FLO. ${ }^{76}$ Producers also get an additional Fairtrade premium, which goes into a communal fund for workers and famers to invest in their communities: for example, for education or healthcare. The decision on how to do this is made democratically: for example, within a farmers' organisation or by workers on a plantation. ${ }^{77}$ The standards also allow producers to request partial pre-payment of the contract. ${ }^{78}$ This is important for small-scale farmers' organisations to

69 For example, when it was deciding on the future of the FAIRTRADE Mark, the FLO invited Fairtrade members, producers, traders and consumers to join them in developing a new strategy, see FLO, Making the Difference: The Global Strategy for Fairtrade (2009) <http://www.fairtrade.se/obj/docpart/c/c6ad566a479f109 $86 \mathrm{c} 87188 \mathrm{~d} 237057 \mathrm{~d} 1$.pdf $>4$. However, Hutchens concluded that the FLO is now so big and market orientated that it has 'effectively invalidated producer and FTO [Fair Trade Organization] voices/knowledge'; Hutchens, above n 59, 130 .

70 FLO, above n 66.

71 Chon, above $\mathrm{n} 23,115$

72 FLO, What is Fairtrade $(2011)<\mathrm{http}$ //www.fairtrade.net $>$

73 FLO, Standards for Small-scale Producer (2011) < http://www.fairtrade.net>

74 FLO, above $\mathrm{n} 72$.

75 Ibid

76 FLO, Frequently Asked Questions (2011) < http://www.fairtrade.net>

77 FLO, Why Fairtrade is Unique (2011) < http://www.fairtrade.net>

78 Ibid. 
ensure they have cash flow to pay farmers. Buyers are required to enter into trading relationships so that producers can predict their income and plan for the future.

A second major difference between Fairtrade and the Australian scheme relates to the certification process. Whereas in the Australian scheme all functions were centralised in the NIAAA, in the Fairtrade system the process for certification is separate from the system's operational management and performed by FLOCERT. ${ }^{79}$ FLO-CERT is ISO 65 certified. ISO 65 is the leading, internationally recognised quality norm for bodies operating a product certification system. ${ }^{80}$ ISO 65 certification guarantees: (1) the existence of a quality management system; (2) transparency in all processes; and (3) independence in the certification decisionmaking. To ensure compliance with ISO 65 rules, FLO-CERT is checked by an independent third party. As part of the certification process, FLO-CERT inspects and certifies producer organisations, and audits traders to check whether they comply with the standards. ${ }^{81}$ The cost of audits - which also include on-site inspections of producers - is charged to the producer wanting to become part of the system. One important reason for the impressive dissemination of Fairtrade among marginalised producers is the financial and administrative assistance offered by FLO for initial applicants. ${ }^{82}$

The marketing aspect is a third major difference between Fairtrade and the Australian scheme. Whereas poor national and international marketing was one of the reasons for the failure of the Australian Authenticity marks, the Fairtrade system's marketing concept is considered crucial for the success of the Fairtrade movement. ${ }^{83}$ The goodwill of Fairtrade is represented internationally by the FAIRTRADE Certification Mark, which is an internationally registered trade mark. The mark is a product label, mainly intended for use on the packaging of products that satisfy the Fairtrade standards. ${ }^{84}$ It allows consumers to buy products in line with their value judgements regarding justice in the northsouth divide. ${ }^{85}$ Consumers' confidence in the FAIRTRADE mark and what it

\footnotetext{
79 Chon, above n 23, 135. Although FLO-CERT is owned by FLO, it is independent, FLO, Certifying Fairtrade (2011) <http://www.fairtrade.net>

80 FLO, above $\mathrm{n} 79$.

81 This includes a review of the organisation's documents (e.g. financial, labour-related, statutes and internal policies) and interviews of organisation members (e.g. members of the Executive Committee and workers). See FLO-CERT, Certification for Development (2010) < http://www. flo-cert.net>

82 The FLO's Producer and Service Relations Unit can support producers to secure and retain certification. Grants amount to 500 euros for initial applications. See FLO, Selling Fairtrade (2011) < http://www.fairtrade. net>

83 FLO, above n 69, 11. See also Hutchens, above n 59, 78-101.

84 FLO, Using the FAIRTRADE MARK (2011) < http://www.fairtrade.net>

85 FLO, Benefits of Fairtrade (2011) < http://www.fairtrade.net>
} 
represents is assured by the high quality of the standardisation and certification processes, and the continued checking of compliance. The mark is now the most widely recognised social and development label in the world. ${ }^{86}$

The FAIRTRADE mark is owned by FLO, but Fairtrade products are marketed by national labelling initiatives or marketing organisations working in twentyfive countries. ${ }^{87}$ The national labelling initiatives may also license out the mark in their countries. The FLO is striving to streamline marketing operations of the national marketing initiatives while taking account of the cultural diversity of all its members and stakeholders. ${ }^{88}$

Finally, the Fairtrade label system is financially sustainable. ${ }^{89}$ Comparatively, one of the reasons why the Australian system was deemed a failure was the lack of financial accountability. ${ }^{90}$

\section{(d) Preliminary Conclusion}

Fairtrade aims to help farmers in developing countries exclusively. The system, moreover, is designed for commodity products. ${ }^{91}$ Accordingly, it would not be possible to extend the current system to creative artefacts produced by indigenous peoples in developed countries such as Australia, New Zealand, the United States and Canada. First, such artefacts include tangible and intangible creations that in many ways are different from commodity products; and, secondly, indigenous peoples in these countries would be excluded from the system because of the development criterion.

Nonetheless, there are lessons that can be learned from the Fairtrade system. One important factor is certainly that Fairtrade did not begin from government or other top-down initiatives, but rather from the people in a grassroots manner. A second aspect is the institutional separation of the certification process from the other two functions of the system. Thirdly, in an environment of globalised markets, including markets for tangible and intangible artefacts of indigenous peoples, marketing strategies for an indigenous origin label must be developed at an international level. Finally, the success of such schemes depends largely on

\footnotetext{
86 At the end of 2008, there were 872 Fairtrade-certified producer organisations in 58 countries, representing over 1.5 million farmers and workers. FLO estimates that 7.5 million people directly benefit from Fairtrade. Over the last five years, sales of Fairtrade-certified products have grown almost $40 \%$ per year (on average) and, in 2008, Fairtrade-certified sales amounted to approximately $€ 2.9$ billion worldwide, FLO, Facts and Figures (2011) < http://www.fairtrade.net>

87 FLO, Fair Trade at a Glance (2010) <http://www.fairtrade.com.au/files/FTF10/Glance.pdf $>1$.

88 FLO, above $\mathrm{n} 69,11$ and 13.

89 FLO, Growing Stronger Together. Annual Report 2009-10 (2010) <http://www.fairtrade.net/fileadmin/ user_upload/content/2009/resources/FLO_Annual-Report-2009_komplett_double_web.pdf > 24-25.

90 Rimmer, above n 27, 163.

91 FLO, Products (2011) < http://www.fairtrade.net/products.html> The products are: coffee, bananas, tea, cocoa, cotton, sugar, full range of herbs and spices, sweet potatoes, melons, olives and olive oil.
} 
sufficient funding for proper marketing and consumer education. In the context of such a system for indigenous peoples, this may mean that strong state support may be required, at least initially.

\section{Compatibility with International Law}

In this section we will investigate how a voluntary standard certifying indigenous origin would relate to the in-progress WIPO legal instruments on TK/TCEs, and whether it would be in conformity with the TRIPS Agreement law and policy-making.

\section{(a) WIPO}

In February 2012, WIPO's IGC met for its 20th session of debates regarding the development of new instruments of international law for the protection of TCE, TK and genetic resources. For the previous six years, divisive discussions in IGC meetings focused on the controversial 2005 draft provisions, prepared by the WIPO IGC Secretariat, for a sui generis protection of TK, TCEs and genetic resources. ${ }^{92}$ In 2007, the WIPO General Assembly renewed the IGC's mandate for two years, during which time there were three sessions but no consensus. ${ }^{93}$ Despite this, in October 2009 the General Assembly of the WIPO decided to renew the IGC's mandate for a further two years. ${ }^{94}$ At the same time it was decided to start formal negotiations based on the draft proposals contained in the document on 'Revised Objectives and Principles' for TCE: that is, the 2005 draft provisions that had originally been prepared by the Secretariat. ${ }^{95}$ In October 2011, the mandate was again renewed for the 2012-2013 biennium. ${ }^{96}$

\footnotetext{
92 WIPO IGC Secretariat, The Protection of Traditional Cultural Expressions/Expressions of Folklore: Revised Objectives and Principles, WIPO Doc WIPO/GRTKF/IC/8/4 (2005).

93 WIPO General Assembly, Report of the Thirty-Fourth (18th Ordinary) Session, Geneva, 24 September to 3 October 2007, WIPO Doc WO/GA/34/16 (2007), para 293(c).

94 WIPO General Assembly, Report of the Thirty-Eighth (19th Ordinary) Session, Geneva, 22 September to 1 October 2009, WIPO Doc WO/GA/38/20 (2009), para 217.

95 Ibid, para 217(c), specifically referring to WIPO IGC Secretariat, The Protection of Traditional Cultural Expressions/Expressions of Folklore: Revised Objectives and Principles, WIPO Doc WIPO/GRTKF/IC/9/4 (2006); WIPO IGC Secretariat, The Protection of Traditional Knowledge: Revised Objectives and Principles, WIPO Doc WIPO/GRTKF/IC/9/5 (2006); and WIPO IGC Secretariat, Genetic Resources: List of Options, WIPO Doc WIPO/ GRTKF/IC/11/8 (a) (2007). No decision was taken on whether these negotiations should lead to a binding or a non-binding instrument.

96 Assemblies of Member States of WIPO, Matters Concerning the Intergovernmental Committee on Intellectual Property and Genetic Resources, Traditional Knowledge and Folklore (Agenda Item 31, Decision, Fortieth, 20th Ordinary Session, 26 September to 5 October 2011).
} 
In its 17th session, the IGC decided to use the results of the Intersessional Working Group on TCE (IWG 1) as the new textual basis for further negotiations. ${ }^{97}$ The IGC also established open-ended drafting groups to streamline the articles on TCEs and to identify any outstanding policy issues. The work of these groups resulted in the document 'The Protection of Traditional Cultural Expressions: Draft Articles', ${ }^{98}$ which was discussed in the IGC's 18th session, the outcome of which was deliberated over in the 19th session in July $2011 .{ }^{99}$

Since the start of the text-based negotiations in the 16th session of the IGC, drafting proposals made by member states have been continuously inserted into the working document, and updated versions have been produced after every session. ${ }^{100}$ The lack of certainty about the general acceptance of these suggested changes makes a substantive analysis of the draft treaty difficult. Furthermore, no decision has yet been taken on whether these negotiations should lead to a binding or non-binding instrument and, even if binding and adopted by the WIPO General Assembly, states can still decide on whether they wish to be signatories or not. Thus, the following discourse is made tentatively.

The current document on TCE provides text that is relevant for certification trade marks. Article 3 of the draft provisions generally distinguishes the scope of and conditions for protection with regard to 'secret' TCEs and 'other' TCEs. Secret TCEs are protected against disclosure and any kind of use. With regard to other TCEs, there are three options. All three alternatives require that indigenous peoples be acknowledged as the source of the TCE, unless this is not possible because of the manner of use of the product. Under Alternative 1, it would be required that, with respect to TCEs which are words, signs, names and symbols, there be a collective right to authorise or prohibit the 'offering for sale or sale of articles that are falsely represented' as TCEs of the beneficiaries, and any use that 'falsely suggests a connection with the beneficiaries' ${ }^{101}$ There is also

97 The IWG is an IGC-established expert group, within which every WIPO member state is represented by one person. It was decided by the IGC that three IWG meetings would take place. IWG 1 on TCE took place in July 2010, and IWG 2 and 3 on TK and Genetic Resources, respectively, took place in February and March 2011. Although IWG is primarily an expert group, it can also draft text proposals for the amendment of the existing draft proposals for revised objectives and principles. The results of IWG 1 are contained in document WIPO IGC, Draft Articles on the Protection of Traditional Cultural Expressions/Expression of Folklore, Prepared at IWG 1, WIPO Doc WIPO/GRTKF/IC/17/9 (2010); IWG 2 in WIPO IGC, Draft Articles on the Protection of Traditional Knowledge, Prepared at IWG 2, WIPO Doc WIPO/GRTKF/IWG/2/3 (2011); and IWG 3 in WIPO IGC, Draft Objectives and Principles Relating to Intellectual Property and Genetic Resources, Prepared at IWG 3, WIPO Doc WIPO/GRTKF/IWG/3/17 (2011).

98 WIPO IGC Secretariat, The Protection of Traditional Cultural Expressions: Draft Articles, WIPO Doc WIPO/GRTKF/IC/18/4 (2011).

99 WIPO IGC Secretariat, The Protection of Traditional Cultural Expressions: Draft Articles, WIPO Doc WIPO/GRTKF/IC/19/4 (2011).

100 Each drafting proposal is accompanied by a footnote indicating the delegation which made the proposal. The first significant alteration to the 2005 draft can be found annexed to WIPO IGC Secretariat, The Protection of Traditional Cultural Expressions/Expressions of Folklore: Revised Objectives and Principles, above n 95.

101 WIPO IGC Secretariat, above n 14, fn 106. 
a provision which allows indigenous peoples to object to any 'false, confusing or misleading indications' on goods or services that suggest an endorsement by or linkage with them. ${ }^{102}$ Alternative 2 is the weakest option and does not mention protection from false misrepresentation. Finally, Alternative 3 states that adequate measures need to protect against the use of 'non-authentic' TCEs in trade 'that suggests a connection that does not exist'.

The working document that was the basis for the negotiations until the $17^{\text {th }}$ session of the IGC provided requirements to prevent misleading indications and false endorsement by, or linkage with, a traditional community that were very similar to Alternative 1 and consistent with Alternative 3 outlined above. In the IGC Secretariat's commentary on Article 3 of the earlier draft, it mentioned a 'handicraft sold as "authentic" or "Indian" when it is not' as a practical example to illustrate the possible implementation of the provisions protecting against 'false or misleading indications in trade' ${ }^{103}$ According to the comment, the suggested principle could be put into practice at the national level through a number of measures, including 'the registration and use of certification trademarks' ${ }^{104}$ Although these comments are not part of the current working document, which is free of comments, they show that a system of voluntary certification for standards on ICH would, in principle, be in conformity with the current IGC draft provisions on TCE.

\section{(b) WTO Law: TRIPS, GATT, GATS, Subsidies and the TBT Agreement}

Together with the prohibition of discrimination, the elimination of tariff barriers and non-tariff barriers to market access of goods and services is a key instrument of trade liberalisation provided by the law of the WTO. In addition, the TRIPS Agreement specifically deals with the implications of IP systems on the conditions of competition in international trade. ${ }^{105}$

\section{(i) TRIPS Agreement}

For certification-mark types of protection for ICH, the TRIPS Agreement is relevant insofar as it incorporates in its section on 'Trademarks' the relevant

\footnotetext{
102 WIPO IGC Secretariat, above $\mathrm{n} 99$, arts $3 \mathrm{C}$ alternative 1.

103 WIPO IGC Secretariat, above n 14, annex 30.

104 Ibid, annex 31.

105 It is the rationale of the TRIPS Agreement to balance the competing private interests of holders of IPRs and the public interest to assure the free flow of goods and services across borders. See T Cottier, 'The Agreement on Trade-Related Aspects of Intellectual Property Rights' in PFJ Macrory et al (eds), The World Trade Organization: Legal, Economic and Political Analysis vol 1 (Springer, 2005) 1041, 1054.
} 
provisions of the Paris Convention. ${ }^{106}$ Article 15.1 TRIPS Agreement provides for a very broad definition of trade marks which covers all types of signs, so long as they are distinctive. ${ }^{107}$ Although certification marks are not specifically mentioned, the TRIPS Agreement does not prevent this type of protection, since Article 1.1 explicitly authorises WTO members to 'implement in their law more extensive protection than is required by this Agreement'. Article 16.1 gives an exclusive right to a trade mark owner for the use of the trade mark 'in the course of trade'. Non-commercial use is not protected. However, this is not a problem when the proposed certification system is intended for traded goods and services. Article 16.2 TRIPS Agreement provides protection of wellknown trade marks that goes beyond the Paris Convention. Whereas the Paris Convention limits the protection of well-known trade marks to trade marks used in respect of identical or similar goods, Article 16.2 TRIPS Agreement extends this protection mutatis mutandis to services, and Article 16.3 extends the protection of well-known marks to non-identical and non-similar goods and services. ${ }^{108}$ These provisions may be relevant if one would consider extending the FAIRTRADE label, which is certainly a famous mark, to services. Finally, Article 18 TRIPS Agreement provides that the registration of a trade mark shall be renewable indefinitely.

\section{(ii) GATT and GATS}

Since the General Agreement on Tariffs and Trade (GATT) and General Agreement of Trade in Services (GATS) obligations for market access and nondiscrimination apply between states, it is difficult to see how non-government voluntary certification standards would be affected by these rules. With regard to Fairtrade and similar schemes, government involvement has recently been discouraged in the European Union. In a 2009 communication, the European Commission concluded that government regulation in this field would hamper the dynamic element of private initiatives and 'could stand in the way of the further development of Fair Trade and other private schemes and their standards' ${ }^{\prime}{ }^{109}$ If a government were to consider regulatory mechanisms relating to private labelling schemes, it would need to comply with existing WTO obligations, in particular

\footnotetext{
106 Provisions on trade marks are enshrined in Articles 15 to 21 under the heading 'Trademarks' in Part II of the Agreement. Article 2.1 of the TRIPS Agreement provides that in respect of (inter alia) Part II of the agreement 'Members shall comply with Articles 1 through 12, and Article 19, of the Paris Convention (1967)'. 107 According to Article 15.1 of the TRIPS Agreement, '[a]ny sign, or any combination of signs, capable of distinguishing the goods or services of one undertaking from those of other undertakings, shall be capable of constituting a trademark'. See D Gervais, The TRIPS Agreement. Drafting History and Analysis (2nd ed, Sweet \& Maxwell, 2003) para 2.160.

108 This is considered to be an important contribution to raised standards of international trade mark protection. See C Correa, Trade Related Aspects of Intellectual Property Rights: A Commentary on the TRIPS Agreement (Oxford University Press, 2007) 188.

109 EU Commission, Communication from the Commission to the Council, the European Parliament and the European Economic and Social Committee, Contributing to Sustainable Development: The Role of Fair Trade and Non-governmental Trade-Related Sustainability Assurance Schemes, EU Com Doc COM (2009) 215 final, 6.
} 
with the principles of non-discrimination, market access and transparency. There exists significant support for the view that a government-led voluntary labelling system would nevertheless be consistent with both the Most-FavouredNation Treatment $(\mathrm{MFN})^{110}$ and National Treatment ${ }^{111}$ obligations. There are also strong arguments that compliance with social standards, such as 'authenticity', could alone be sufficient to make products non-'like' and, thus, allowably differentiated. ${ }^{112}$

\section{(iii) Subsidies}

Government support for a labelling system could be considered a subsidy. The law of the WTO provides rules on subsidies for goods but not for services. ${ }^{113}$ Under the Agreement on Subsidies and Countervailing Measures (SCM Agreement), some subsidies are strictly forbidden if they are contingent on export performance or on the use of domestic over imported goods (Article 3.1), and others are actionable if they cause 'adverse effects' on another member (Article 5). According to Articles 1 and 2 of the SCM Agreement, a subsidy is defined

110 According to the 1991 GATT Panel Report, United States - Restrictions on Imports of Tuna I (Mexico) GATT Doc BISD 39S/155 (1991, unadopted) paras 5.42-5.43, this is so even if an 'authentic' good and a 'nonauthentic' good are considered 'like products'. In that case, the panel decided that the US Dolphin Protection Consumer Information Act, according the right to use the label 'Dolphin Safe' for tuna harvested in the Eastern Tropical Pacific Ocean only if such tuna was accompanied by documentary evidence showing that it was not harvested with purse-seine nets intentionally deployed to encircle dolphins, was consistent with the MFN obligation (Article I GATT). In assessing MFN compliancy, the panel found that voluntary labelling for production or processing methods (PPMs), which do not affect the characteristics of the end product, are MFN compliant, as they do not restrict trade. Even though there was government involvement, a voluntary labelling system that ultimately affected the market only through the free choice of the consumer was stated not to be an 'advantage' granted by the state. Although the report was not adopted, the panel's decision concerning voluntary single-issue labelling remains largely unchallenged. See C Dankers, Environmental and Social Standards, Certification and Labelling for Cash Crops, Food and Agriculture Organization of the United Nations (UN FAO, 2003) 74, citing A E Appleton, Environmental Labelling Programmes: International Trade Law Implications (Kluwer Law International, 1997) 145.

111 The application of the National Treatment obligation to such voluntary labelling systems has never been assessed by a WTO Panel or the Appellate Body, whether state-supported or not. Even where there is state support for a voluntary labelling system, such a measure would not be a tax (Article III:2), a regulation or requirement (Article III:4) or any other measure mentioned in Article III:1 GATT. Furthermore, it is unlikely that the system would be perceived as 'affecting the internal sale offering for sale, purchase, transportation, distribution or use of products' (Article III:4), due to the voluntary nature. See Dankers, ibid 74-75, citing Appleton, ibid 153.

112 In GATT Panel Report, United States - Restrictions on Imports of Tuna I (Mexico), above n 110, para 5.15, it was found that non-product-related (NPR) PPMs could not affect the 'likeness' of end products. However, this has been questioned by $\mathrm{P}$ Van den Bossche, The Law and Policy of the World Trade Organization (2nd ed, Cambridge University Press, 2008) 381, stating that a more 'nuanced' approach is now required, as NPRPPMs can affect consumer tastes and preferences. Since this, in turn, affects the NPR-PPMs' competitive and substitutive nature, the use of such measures would affect the likeness of an end product. However, Van den Bossche cautions that this would rarely occur, as most markets are driven by price rather than concern over conformity with social standards.

113 Although Article XV GATS calls upon members to develop disciplines to avoid trade-distortive effects of subsidies, this is still a leftover. See P Sauvé, 'Completing the GATS Framework: Addressing Uruguay Round Leftovers' (2002) 57(3) Aussenwirtschaft 301, 324-333; P Poretti, 'Waiting for Godot: Subsidy Disciplines in Services Trade' in M Panizzon et al (eds), GATS and the Regulation of International Trade in Services (Cambridge University Press, 2008) 466-488. 
as: (1) a financial contribution by a public body; (2) that confers a benefit; (3) to a specific enterprise or industry. The concept of 'financial contribution' is not limited to a direct transfer of funds, but includes reduction of costs, tax breaks ${ }^{114}$ or other fiscal incentives to an industry. ${ }^{115}$ On the other hand, the requirement of a 'financial contribution' means that not all government measures that confer a benefit are subsidies. ${ }^{116}$

Even if state funded, a support scheme, such as the Australian Authenticity Label, would not constitute a 'subsidy', as it would not be a financial contribution, as required by Article 1.1 SCM Agreement, or take the form of income or price support in the sense of Article XVI GATT. The funding of a trade mark would neither reduce the costs of producers (for example, in production or in the export process) nor directly affect production. It would be neither contingent on export performance nor trade distorting (directly artificially increasing exports), and would not affect comparative advantage ${ }^{117}$ Moreover, Article 14(d) of the SCM Agreement states that the provision of governmental services is not to be considered as conferring a benefit, if the service is provided for adequate remuneration. Thus, a financially self-sustaining certification system (such as the Fairtrade system, through membership fees and other income) ${ }^{118}$ would be compliant with the SCM Agreement. Even if fulfilling the other requirements of a 'subsidy', the funding of a trade mark for authentic indigenous cultural products would be considered general and not specific, as it would apply to more than one enterprise, industry or region, ${ }^{119}$ and would not be dependent thereon.

\section{(iv) TBT Agreement}

With regard to technical regulations and standards for the trade in goods, the Agreement on Technical Barriers to Trade (TBT) must be respected to ensure that they do not create unnecessary obstacles to international trade. ${ }^{120}$

114 Whereas tax breaks discriminating between foreign and domestic goods would violate Article III(2) GATT, it seems likely that WTO Panels or the AB would consider a non-discriminatory tax cut a financial contribution within the meaning of Article 1.1 SCM. See C B Graber, 'State Aid for Digital Games and Cultural Diversity: A Critical Reflection in the Light of EU and WTO Law' in C B Graber and M Burri-Nenova (eds), Governance of Digital Game Environments and Cultural Diversity: Transdisciplinary Perspectives (Edward Elgar, 2010) 170, 199.

115 Van den Bossche, above n 112, 562; SCM Agreement, Article 1.1(1)(a).

116 WTO Panel Report, United States - Measures Treating Exports Restraints as Subsidies, WTO Doc WT/ DS194/R (2001), paras 8.65 and 8.73 .

117 WTO Panel Report, Australia - Subsidies Provided to Producers and Exporters of Automotive Leather, WTO Doc WT/DS126/R (1999). The concept of trade distortion is also used and clarified by the Appellate Body, in WTO Appellate Body Report, Canada - Measures Affecting the Export of Civilian Aircraft, WTO Doc WT/DS70/AB/R (1999), para 157.

118 FLO, above n 89, 24-25.

119 Van den Bossche, above n 112, 568; SCM Agreement Articles 1.2 and 2.

120 Preamble of the TBT Agreement. For a comprehensive analysis of the TBT Agreement, see R Wolfrum et al (eds), WTO - Technical Barriers and SPS Measures (Martinus Nijhoff Publishers, 2007). 
The TBT Agreement covers packaging, marking and labelling requirements, and procedures for assessing conformity with the technical regulations and standards. ${ }^{121}$ Since 'regulations' are mandatory for the purposes of the Agreement, a voluntary labelling system would be a 'standard' rather than a 'regulation'. Under the TBT Agreement, the requirements for voluntary systems are less stringent than those for mandatory systems. ${ }^{122}$ 'Standard' is defined as:

Document approved by a recognized body, that provides, for common and repeated use, rules, guidelines or characteristics for products or related processes and production methods, with which compliance is not mandatory. It may also include or deal exclusively with terminology, symbols, packaging, marking or labelling requirements as they apply to a product, process or production method. ${ }^{123}$

Although 'recognized body' is not defined in the TBT Agreement, it is not limited to governments or public authorities, but may also include non-governmental standardising bodies. ${ }^{124} \mathrm{~A}$ 'non-governmental body' is a body other than a central government or local government body, ${ }^{125}$ and includes 'a non-governmental body which has legal power to enforce a technical regulation'. ${ }^{126}$ Private organisations managing the proposed label would fall into this definition.

It is evident that the TBT Agreement applies to processes and production methods (PPMs). However, there remain several open questions with regard to whether an authenticity standard for product differentiation would be covered by the TBT Agreement. To begin with, it is not clear whether such a standard would be product related. ${ }^{127}$ Assuming that such a standard is non-product related (NPR),

\footnotetext{
121 Preamble of the TBT Agreement.

122 Interestingly, countries often argue against the differentiation between mandatory and voluntary standards, saying that, because the standard creates market segregation, compliance with the standard becomes de facto mandatory. See Dankers, above n 110, 76, citing a submission made in 2001 by Switzerland to the WTO Committee on Trade and Environment, 'Marking and Labelling Requirements', WTO Docs WT/CTE/W/192 and G/TBT/W/162 (2001). See also Kommerskollegium National Board of Trade, Global Trade Division, Sweden, 'Eco-Labelling and the WTO: Issues for Further Analysis and Clarification', (Report No. 119-007-2002, 2002) 5. However, this would not be the case with the proposed standard and labelling system, as it would not be possible for everyone to apply for the certification, thus it is not possible for it to be de facto mandatory.

123 TBT Agreement, annex 1, para. 2 [emphasis added].

124 Van den Bossche, above n 112, 813-814.

125 'Central government body' and 'local government body' are defined in TBT Agreement annex 1, paras 6 and 7 respectively.

126 Ibid, annex 1, para 8.

127 It is also not clear whether authentic and non-authentic products would be like. In addition, the concept of 'likeness' has not yet been clarified under the TBT Agreement (but is relevant for the assessment of conformity with the MFN and National treatment principles within the TBT Agreement and the annexed Code of Good Practice). Whereas 'likeness' has been expounded upon by Panels and the Appellate Body in the realm of Articles I and III GATT, it must be recalled that the concept of 'like products' may have a different meaning in the different contexts it is used. According to Van den Bossche, above n 112, 818, structural differences between the GATT and the TBT Agreement stand in the way of applying this GATT-related case law to the TBT Agreement. Whereas the assessment of 'likeness' in general depends greatly on the consumer perception of the goods at issue, 'likeness' and 'product-relatedness', under the TBT Agreement, are much more technical
} 
it is furthermore uncertain whether the TBT Agreement would be applicable at all, ${ }^{128}$ since there has been a lot debate regarding the interpretation of the concept of 'standard' as defined in Annex 1 to the TBT Agreement. The first sentence of the definition of 'standard' (as outlined above) specifically mentions productrelated PPMs, but the second sentence (which deals with marking or labelling requirements) leaves the word 'related' out. ${ }^{129}$ Apparently, the negotiators failed to agree on whether NPR-PPMs for terminology, symbols, packaging, marking or labelling requirements would be covered by this definition. Whereas Van den Bossche $^{130}$ favours a text-based interpretation that would include NPR-PPMs, other authors have argued for a contrary view. ${ }^{131}$

To be sure, even if the standard of authenticity were covered by the TBT Agreement, its reach would be limited, because - like in all other WTO law - only government actions are regulated. Article 4.1 of the TBT Agreement requires full compliance only from central governmental bodies, and members need only to take 'reasonable measures' as may be available to them to ensure non-governmental bodies' and local governmental bodies' ${ }^{\prime 32}$ compliance with the 'Code of Good Practice for the Preparation, Adoption and Application of Standards'. ${ }^{133}$ There is no WTO case law explaining what 'reasonable measures'

in nature. It has also been argued that the fact that the TBT Agreement offers no explicit exceptions to MFN and National Treatment (unlike in GATT), 'like' may be read more narrowly, otherwise members would be left little room to distinguish products for environmental, health or social reasons, as allowed by Article XX GATT. N Bernasconi-Osterwalder et al, Environment and Trade: A Guide to WTO Jurisprudence (Earthscan, 2006) 16, 215.

128 No WTO Panel or Appellate Body has yet looked at the applicability of the TBT Agreement to voluntary standards that are NPR-PPMs. Bernasconi-Osterwalder, above n 127, 207. The TBT Committee discusses the applicability of the TBT Agreement to NPR-PPMs (J. Stein, 'The Legal Status of Eco-Labels and Product and Process Methods in the World Trade Organization' (2009) 1(4) American Journal of Economics and Business Administration 285, 287). The Committee on Trade and Environment has also been tasked with considering the relationship between WTO provisions and environmental standards, due to the recent trend of eco-labelling: WTO Environment: Issues Labelling (2011) < http://www.wto.org/english/tratop_e/envir_e/labelling_e.htm> 129 Dankers, above n 110, 76; Bernasconi-Osterwalder et al, above n 127, 214; M Koebele, 'Agreement on Technical Barriers to Trade. Article 1 and Annex 1 TBT' (2007) in R Wolfrum et al (eds), above n 120, 178, 196. 130 Van den Bossche, above n 112, 808-809.

131 See Dankers, above n 110, 77, citing Appleton, above n 110, 93-94, 124; Bernasconi-Osterwalder et al, above n 127, 214; Koebele, above $\mathrm{n}$ 129, 196-197. They argue that the second sentence must be read in light of the first, as the second sentence was never meant to be a stand-alone provision, and that NPR-PPMs arguably were not intended to be covered by the TBT Agreement, which is indicated by the negotiation history. These arguments appear to give much weight to the negotiation history. However, according to the Vienna Convention on the Law of Treaties (VCLT), 'preparatory work' should only be a supplementary means of interpretation in the sense of Article 32 VCLT.

132 This is contrary to general international law, which holds states responsible for all governmental actions, regardless of whether central or local. See M Koebele and G LaFortune, 'Agreement on Technical Barriers to Trade. Article 4 and Annex 3 TBT' (2007) in R Wolfrum et al (eds), above n 120, 243, 255-256.

133 The Code can be found at TBT Agreement, annex 3. 
means in the TBT context. ${ }^{134}$ In any case, these are only 'best effort' or 'secondlevel' obligations of members. ${ }^{135}$ Moreover, there is nothing to suggest that the proposed system would be contrary to the Code. ${ }^{136}$

In conclusion, whereas the TRIPS Agreement provides for positive protection for certification trade marks, there is no evidence suggesting that voluntary certification standards - even if government supported — would not be consistent with the GATT, the GATS, or the TBT and the SCM Agreements.

\section{Conclusion}

The burgeoning market for indigenous goods and services has resulted in a parallel increase in the production of non-authentic products of this nature. In recognition of this, many label schemes have been initiated in an attempt to validate authenticity, and educate and sway consumers away from nonauthentic products. However, none of these has achieved success comparable with the Fairtrade label. Indeed the Australian certification label system was shut down after only two years of operations, and the New Zealand Māori-made (toi iho) system was disinvested by the government in late 2009.

The four main structural reasons for the failure of the Australian system were: (1) the 'top-down' nature of the system and the poor consultation with the relevant stakeholders prior to its inception; (2) difficulties in defining the standard of 'authenticity' and then controlling what fell into this; (3) non-independence of the certifier, which was the same body that set the standards and owned the trade marks; and (4) poor funding of the system, which meant an inability to market the initiative adequately in Australia, let alone internationally. Conversely, the FLO Fairtrade scheme started as a 'bottom-up' initiative and continues to integrate stakeholder involvement into every aspect of its decisionmaking processes, including the setting of standards. Moreover, certification is not performed by the FLO, but by FLO-CERT. Though owned by FLO, FLO-

\footnotetext{
134 Bernasconi-Osterwalder et al, above $\mathrm{n}$ 127, 207. The term 'reasonable measures' was derived from Article XXIV:12 GATT, which requires that a member 'shall take such reasonable measures as may be available to it to ensure observance of the provisions of this Agreement by the regional and local governments and authorities within its territories.' It is limited in scope to situations where the central government body is in the position to direct or influence compliance, e.g. if there are legal means available for this. Political resistance or sensitivity would not be sufficient to deter the obligation, but requiring a change in law (particularly constitutional law) would likely not be reasonable. See ibid, 225-257.

135 Koebele and LaFortune, above n 132, 255; R Muñoz, 'Agreement on Technical Barriers to Trade: Article

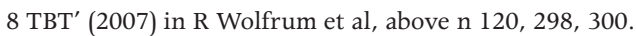

136 The Code of Good Practice includes requirements of MFN and National Treatment and promotes international harmonisation and the avoidance of duplication of the work of other standardising bodies. Standards should not restrict trade unnecessarily and should be published 60 days before adoption to allow interested parties to submit comments. These are outlined and discussed in Koebele and LaFortune, above $\mathrm{n}$ 132, 247-253.
} 
CERT is a completely autonomous and independent organisation. FLO-CERT is also ISO 65 certified, which ensures (a) a quality management system; (b) transparency; and (c) independence in decision-making. Finally, Fairtrade is financially self-sufficient and well marketed around the world.

In Australia, there is some movement towards using a fair trade scheme and a voluntary labelling system for indigenous TK/TCEs. ${ }^{137}$

It is not perceived that a voluntary certification system for TK/TCEs would be contrary to either WIPO or WTO law or policy. Such a system is in conformity with the current line of thought in the WIPO forum. Regarding WTO law, a voluntary certification system appears to be consistent with the GATT and the SCM Agreement. The most relevant agreement is likely to be the TBT Agreement. TBT compliance of a voluntary scheme has never been assessed by any WTO dispute body and it is thus not clear whether it would fall into the Agreement's scope. Much of this would depend on whether the standard of authenticity was deemed to be 'product related' and capable of making authentic and nonauthentic products non-'like'. Compliance would also depend on whether the system is supported by central government or not. In any case, the voluntary system would not be contrary to any of the principles of the TBT Agreement (including MFN and National Treatment) or the Code of Good Practice.

The extension of the FLO Fairtrade system to TK/TCEs would be problematic. One of the options that Australia is looking at is co-branding through a joint Fairtrade label. ${ }^{138}$ Currently, not all producers qualify to apply for the Fairtrade label. ${ }^{139}$ Moreover, the products for which the mark can be used are also limited and include only commodity products. ${ }^{140}$ The FLO has indicated its plan to widen the range of people able to benefit from the system, including adding more countries and more products. ${ }^{141}$ Indeed, the FLO recently added the first service to its mandate, now certifying travel tours. ${ }^{142}$ However, the FLO has admitted that introducing new products is slow and costly because of the great deal of research that is involved in assessing whether the introduction will really benefit the producers. ${ }^{143}$ It is difficult to create standards (particularly those that can be consistently certified) for handicrafts and other products (and services) made by small-scale producers, each of which may be unique

\footnotetext{
137 M Spencer and J Hardie, Indigenous Fair Trade in Australia: Scoping Study (Australian Government Rural Industries Research and Development Corporation, 2010).

138 Ibid.

139 See above $\mathrm{n} 65$.

140 See FLO, above n 91.

141 FLO, above $\mathrm{n} 87,2$.

142 'Fair Trade hält auch in der Reisebranche Einzug' Neue Zürcher Zeitung (2010) <http://epaper.nzz.ch/ nzz/forms/page.html>

143 FLO, above n 76.
} 
and involve varying production processes and costs. ${ }^{144}$ Consequently, it could be argued that the Fairtrade system is more suited for TK- rather than TCErelated products. However, given the large variety of agricultural goods among indigenous communities, the creation of standards could prove complicated even for these goods. Moreover, considering the difficulties in getting different Australian Aborigines to identify with an Australian labelling system, it may be equally (if not more) problematic to convince many different indigenous peoples from around the world to stand behind a pan-global label which is to some extent meant to reflect identity. ${ }^{145}$ The vast differences between indigenous communities would make the creation of the standards logistically difficult. Finally, it is worth noting that the democratic structure required under the FLO general standards could contradict the customs of certain indigenous communities.

Although the idea of employing the FLO scheme for indigenous purposes is tempting, a great deal of research would be needed to make this work. An avenue to explore could be the formulation of only one set of FLO standards for all indigenous products or services, aside from those otherwise certified by the FLO. These standards would have to be quite broad and general, and capable of covering a wide range of products or services. A difficult question to resolve would be what exactly it is they should address. Moreover, we suggest studying the possibilities of interfacing 'Fairtrade philosophy' with existing marketing structures successfully operated by indigenous people at the local level, such as the Aboriginal cultural centres that exist in Australia. These centres could be of help in the most difficult task of developing a standard of 'Aboriginal origin' or 'Aboriginal authenticity' that would be accepted by indigenous people (locally) while, at the same time, complying with broader FLO standards (globally).

\section{Acknowledgements}

The authors would like to thank Maggie Chon, Benny Müller and Matthias Oesch. The support from the Swiss National Science Foundation and the Ecoscientia Foundation is gratefully appreciated. This chapter is an updated version of an article published in (2011) 39(3) Prometheus 287, which was based on a paper presented at a conference hosted by NZCIEL in December 2010. The authors would like to express thanks to Susy Frankel and Peter Drahos for hosting the conference and for their comments on earlier versions of the text.

144 Ibid. For a discussion on the use and problems of non-FLO fair trade labels on craft products, see Zografos, above n 24, 155-159.

145 This could be a particular issue given the problem outlined by Hutchens, above n 69. 